\title{
Reducing the Carbon Footprint: Primary Production of Aluminum and Silicon with Changing Energy Systems
}

\author{
Gudrun Saevarsdottir ${ }^{1}\left[\right.$ Thordur Magnusson $^{2} \cdot$ Halvor Kvande $^{3}$
}

Received: 31 March 2021 / Accepted: 16 August 2021 / Published online: 31 August 2021

(c) The Author(s) 2021

\section{Abstract}

The world now pushes for a low-carbon future, and international goals for greenhouse gas emission reductions have been set. Industrial processes, including metallurgical processes, make up more than a fifth of the total global emissions, and those have been rising with infrastructure development and the expansion of the middle-class worldwide. This paper focuses on two energy-intensive processes, aluminum production and metallurgical grade silicon production, and how the carbon footprints from these industrial processes have developed in recent decades. The main trend is that the increased demand for these metals has led to expanding primary production for both of them, based on energy with an increasing share of fossil-based electric power. In fact, the average carbon footprint of the energy used in aluminum and silicon production has increased by $38 \%$ and $43 \%$, respectively, from 2000 to 2019 . The change in energy mix offsets any progress in process efficiencies. This work addresses this and discusses opportunities for improvements.

\section{Graphical Abstract}

\section{Reducing the Carbon Footprint from Primary Production of Aluminum and Silicon}
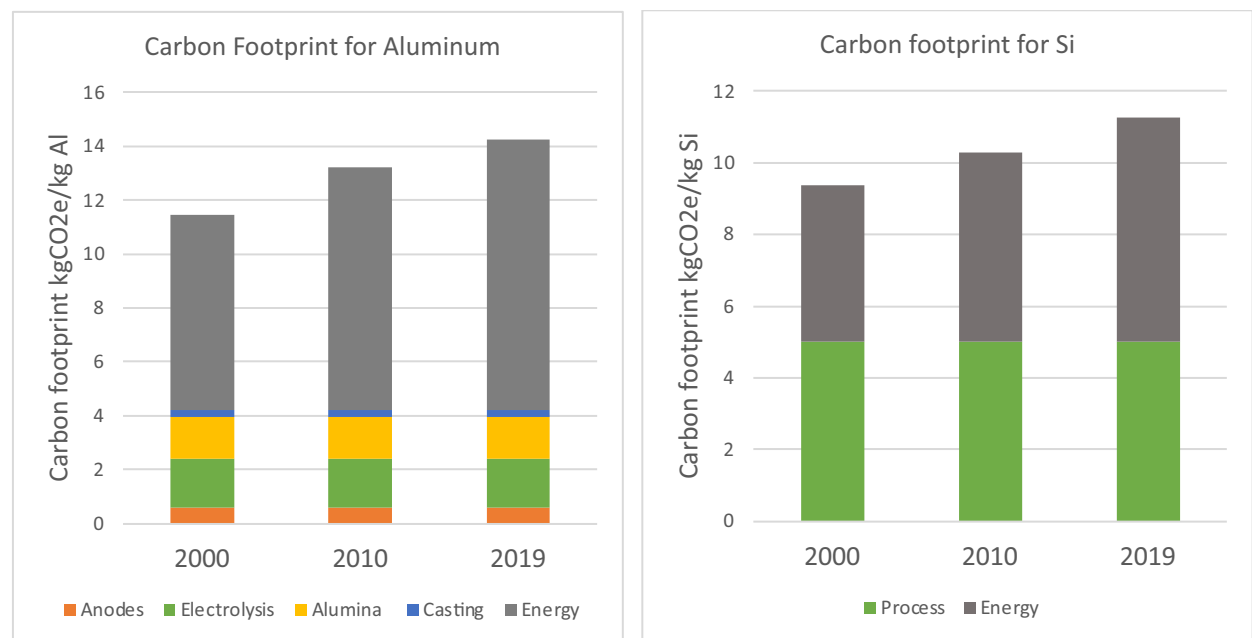

Development of carbon footprint for Al and Si since 2000

Keywords Aluminum production $\cdot$ Silicon production $\cdot$ Carbon footprint $\cdot$ Indirect emissions $\cdot$ Energy related emissions

The contributing editor for this article was Joo Hyun Park.

Extended author information available on the last page of the article 


\section{Introduction}

The Paris agreement has as an aim to limit the global warming to well below $2{ }^{\circ} \mathrm{C}$, and preferably to $1.5^{\circ} \mathrm{C}$. It is a legally binding international treaty and has been adopted by 196 countries. The world is pushing for a low-carbon future in order to limit climate change. The most recent report from IPCC [1] states that the total greenhouse gas emissions in 2030 must have fallen by $45 \%$ from 2010 levels, and that "net zero" has to be achieved around 2050, to prevent more than $1.5^{\circ} \mathrm{C}$ rise in temperature.

At the same time, populous regions of the world are developing rapidly, and the number of people enjoying a middle-class lifestyle is increasing, which increases consumption. This is unavoidably associated with the rapid development of infrastructure and increased demand for necessary materials. According to a recent review article by Davis et al. [2], direct emissions from industrial processes are the source of around a quarter of all global greenhouse gas emissions, and these are among the emissions that will be the hardest to eliminate. While there are alternatives available for reducing emissions from electric power production, industrial processes such as cement and steel production are more challenging, as alternative emission-free processes are not available at industrial scale at this time.

This is also true for other materials. Aluminum and silicon are examples of materials that have seen rapid growth in demand in recent years, which has been met by expanding primary production. Since year 2000 , the primary production of aluminum and metallurgical grade silicon has increased by a factor of 2.6 and 2.4, respectively. This paper addresses how this has affected the carbon footprint for these two metals that fall into the category of light metals, which together consume around $70 \%$ of the electric power produced in Iceland. To be accurate, silicon is a semiconductor and not a metal, which indeed is integral to its use in electronics, but for the purpose of the production process it behaves as a metal and it will therefore be referred to as one in this paper.

Silicon is a very useful material for many applications [3]. By volume, the largest application is as an alloying element in cast alloys of aluminum, used for example in engine blocks, cylinder heads and machine tools, and through ferrosilicon as a deoxidising agent for steel and to make dynamo and transformer plates. Silicon is also used to make silicones, which are silicon-oxygen polymers with methyl groups attached. Silicon rubber makes a waterproof sealant, and silicone oil is a lubricant, which is added to some cosmetics and hair conditioners. Purified solar grade silicon is used in photovoltaics, and hyper pure, electronic grade silicon is the dominating semiconductor used in solid-state devices in computers and microelectronics. Most MG silicon is used as an ingredient in other materials, so recycling back to silicon metal is not feasible in most cases.

Aluminum has a density of $2.7 \mathrm{~kg} / \mathrm{dm}^{3}$ at room temperature, which is about one-third of the density of iron and steel. With proper alloying and microstructure, a high strength-to-weight ratio can be achieved, along with great flexibility for efficient formability into complex shapes using modern design features [4]. Aluminum is also durable, and aluminum products often serve for decades in use. Therefore, only around $20 \%$ of the current demand can be met with end of life recycled material, and $34 \%$ if new scrap is included [5]. Aluminum is, however, infinitely recyclable, which requires only around $5 \%$ of the energy demand for primary production, making it a perfect candidate for a circular economy [6]. A significant proportion of the products arising from the finished articles using aluminum contributes to energy saving due to the light weight, and thus reducing the carbon dioxide emission that would otherwise arise from the population. The most common uses of aluminum include construction (buildings and structures), transportation, electrical conductors, and packaging.

The carbon footprints are composed of direct emissions from the production process, the raw materials for the production processes, as well as indirect emissions that are inferred when producing the electrical energy used to power the production processes. This paper will address both these types of emission sources and discuss strategies to reduce or eliminate these emissions.

\section{The Aluminum Production Process}

Aluminum occurs in nature in the form of chemically very stable compounds, in particular oxides. The raw material for aluminum production, alumina $\left(\mathrm{Al}_{2} \mathrm{O}_{3}\right)$, is refined from bauxite, which is an ore mined from strip mines. The production process also requires carbon anode production, electrolysis, casting, and secondary metal treatment. The following approximate amounts of raw materials are needed to produce $1 \mathrm{~kg}$ of aluminum from alumina by electrolysis [7]:

- $2.0 \mathrm{~kg}$ of smelter-grade cell-feed secondary alumina $\left(\mathrm{Al}_{2} \mathrm{O}_{3}\right)$ from dry scrubbers

- 0.40 to $0.46 \mathrm{~kg}$ of carbon (in the form of carbon anodes used in the electrolysis process)

- 12.5 to $16 \mathrm{kWh} / \mathrm{kg} \mathrm{Al}$ of electrical energy (direct current, DC).

Aluminum is produced by the Hall-Héroult process, where the alumina is dissolved in a sodium-aluminum-fluoride molten salt mixture (mainly cryolite, $\mathrm{Na}_{3} \mathrm{AlF}_{6}$ ) at about $960{ }^{\circ} \mathrm{C}$ to form an ionic conducting medium that enables the 
products to be formed via three processes that occur between the two electrodes [8]:

- electrochemical reduction of the aluminum-containing species to aluminum metal at the cathode

- electrochemical oxidation of the oxide-containing species with the carbon anode to predominantly form $\mathrm{CO}_{2}$ but also some $\mathrm{CO}$

- energy (heat) transfer to enable the reaction products to achieve a state that enables removal from the cell.

Ideally, the overall stoichiometry of the electrochemical reaction in the cell is:

$1 / 2 \mathrm{Al}_{2} \mathrm{O}_{3}$ (dissolved) $+3 / 4 \mathrm{C}(\mathrm{s})=\mathrm{Al}(\mathrm{l})+3 / 4 \mathrm{CO}_{2}(\mathrm{~g})$

But a part of the oxygen will react to form $\mathrm{CO}$ :

$1 / 2 \mathrm{Al}_{2} \mathrm{O}_{3}$ (dissolved) $+3 / 2 \mathrm{C}(\mathrm{s})=\mathrm{Al}(\mathrm{l})+3 / 2 \mathrm{CO}(\mathrm{g})$

In fact, the formation of CO by Eq. (2) is thermodynamically favored, but fortunately, due to kinetics $\mathrm{CO}_{2}$ is the primary anode product, while carbon monoxide is also coevolved. The electrode must nevertheless be polarized sufficiently to lift the electrode potential above that of carbon monoxide formation, so there is always some direct electrochemical formation as well as quite a bit of indirect reaction [7]. Virtually all of the $\mathrm{CO}$ is oxidized in the flame of the cell gases, an almost spontaneous reaction with the oxygen of air mixing, as the thermodynamic equilibrium between $\mathrm{CO}, \mathrm{O}_{2}$, and $\mathrm{CO}_{2}$ favors $\mathrm{CO}_{2}$ at low temperatures. This increases the $\mathrm{CO}_{2}$ emissions from the stoichiometry of Eq. (1).

If the electrolyte gets depleted of alumina, but the current still passes through the cell, the anode voltage will become sufficient to oxidize electrolyte components and perfluorocarbon (PFC) gases will be evolved at the anode. This phenomenon is called anode effect. These gases, mostly $\mathrm{CF}_{4}$ and $\mathrm{C}_{2} \mathrm{~F}_{6}$ are extremely potent greenhouse gases, with between 6600 and 11,100 times the greenhouse gas potential of $\mathrm{CO}_{2}$ and they have historically contributed with almost half the greenhouse gas emissions from the electrolysis process [9]. But as awareness of this arose in the 1980s, the industry has focused on reducing the frequency and duration of anode effects, which now contribute to less than $2 \%$ of the carbon footprint [10]. PFC co-evolution also occasionally occurs at much lower rates in localized zones of the cell, when operating conditions change through spatial or operating reasons and the interfacial potential at the anode exceeds a critical value. The main operating factors that cause this localized potential increase are the presence of zones where the alumina concentration has dropped substantially, or the anodes are carrying a very high electrochemical current density. The propensity for the occurrence of such continuous emissions is higher in large cells with high amperage [11].

The contribution from process emission sources in the aluminum production process are summarized in Table 1.

\section{The Silicon Production Process}

Metallurgical Grade silicon (MG silicon) is produced in submerged arc furnaces by carbothermic reduction of quartz. The main raw materials are $\mathrm{SiO}_{2}$ in the form of quartz and carbon materials that consist of coal, coke, charcoal, and woodchips. In this continuous process, the raw materials are fed into a submerged arc furnace (SAF) from above, and are penetrated by electrodes, in most cases three electrodes carrying three-phase electric current, that form a star connection in the furnace. Ideally, the stoichiometry of the overall reaction in the furnace can be written as [12]

$\mathrm{SiO}_{2}(\mathrm{~s})+2 \mathrm{C}(\mathrm{s})=\mathrm{Si}(\mathrm{l})+2 \mathrm{CO}(\mathrm{g})$

This stoichiometry is a result of a series of sub-reactions, and the raw material charge consists of partially reacted raw materials and intermediate reaction products further down in the furnace. The current flows from the electrodes submerged in the charge, through the material filling the furnace, and to a large extent passes through an electric arc as it leaves the electrode.

One of the most important parameters for this process is the fraction of incoming $\mathrm{Si}$ in quarts, which is tapped as metal, also termed silicon yield. As the metal producing reaction deep in the furnace needs almost $2000{ }^{\circ} \mathrm{C}$ to obtain a good silicon yield from the process, the presence of electric arcs is important for the yield, and thus for both emissions and energy consumption.

It is the stoichiometry of Eq. (3), which accounts for most of the greenhouse gas emissions from the MG-silicon production process, decided by the four-valent $\mathrm{Si}$ in quarts and thermodynamics, which favor the formation of $\mathrm{CO}$ gas rather than $\mathrm{CO}_{2}$. The stoichiometric production of $\mathrm{CO}_{2}$ is $3.26 \mathrm{~kg}$ for each $\mathrm{kg}$ of $\mathrm{Si}$ metal produced. This is unavoidable for a carbothermic process, as carbon is needed to capture the oxygen from the quarts, leaving the metal behind. In the actual furnace there are inefficiencies and losses that increase the carbon consumption per unit metal produced. As an example, $\mathrm{SiO}$ gas, which is one of the intermediate products in the process, escapes the process in some amount to form silica fumes reducing the silicon yield. Thus, the greenhouse gas emissions, as well as the energy consumption of the process, are closely linked to the silicon yield for the process. The process emission factor for $\mathrm{MG}$ silicon as reported in the IPCC guidelines [13, 14] as well as Lindstad et al. [15] is estimated as $5 \mathrm{~kg} \mathrm{CO}_{2} /$ ton silicon metal. 
Table 1 Typical process emissions for aluminum production based on an estimate in [7]

\begin{tabular}{lll}
\hline Processes & $\begin{array}{l}\text { Global average } \mathrm{CO}_{2} \\
\text { emissions } \\
(\mathrm{t} \mathrm{CO} 2 \mathrm{e} / \mathrm{t} \mathrm{Al})\end{array}$ & $\begin{array}{l}\text { Best Available Technology } \\
(\mathrm{BAT}) \text { emissions }\left(\mathrm{t} \mathrm{CO}_{2} \mathrm{e} / \mathrm{t}\right.\end{array}$ \\
\hline Bauxite mining & 0.03 & 0.03 \\
Alumina production & 1.5 & 1.4 \\
Calcined petroleum coke production & 0.3 & 0.3 \\
Carbon anode production (anode baking) & 0.3 & 0.2 \\
Cathode and spent potlining (SPL) & 0.03 & 0.03 \\
Net cell carbon consumption & 1.5 & 1.4 \\
Perfluorocarbon (PFC) emissions & 0.2 & 0.02 \\
Ingot casting related to fuel combustion & 0.3 & 0.1 \\
Total from process & 4.2 & 3.5 \\
\hline
\end{tabular}

This estimate is based on assuming no use of biocarbon, apart from an unspecified minimum amount of woodchips. Monsen et al. [16] estimated an emission factor of 4.68, assuming that around $10 \%$ of the carbon used originates from biocarbon. As most smelters use a significant share of biocarbon, that number is used by Saevarsdottir et al. [17], but the more conservative estimate of $5 \mathrm{~kg} \mathrm{CO}_{2} /$ ton silicon metal used by IPCC serves as a basis for the estimates in this paper. It should be noted that any fraction of biocarbon in the reductant mix should be accounted for by reducing the emission factor, but as the focus of this paper is on the effect of the energy mix, the IPCC carbon footprint is used for all regions. Regional variation in the process carbon footprint based on the use of biocarbon is a topic for another study.

\section{The Indirect Emissions}

As addressed in the introduction, the demand for both aluminum and silicon has increased rapidly in recent years, a trend which is likely to continue. In fact, the primary production of aluminum and metallurgical grade silicon has increased by a factor of 2.6 and 2.4, respectively, since 2000 . The production of both these metals is characterized as energy intensive, as both processes require significant electrical energy for their operation. This is different from, for example, iron production, which runs mostly on the chemical energy in the reduction agents used in the process and does not require much electrical energy. Aluminum requires $12.5-16 \mathrm{kWh} / \mathrm{kg} \mathrm{Al}$ in the electrolysis process, while the specific electrical energy consumption for MG-silicon production is in the range of $10.5-13 \mathrm{kWh} / \mathrm{kg} \mathrm{Si}$. Therefore, the energy mix for the production of the electric power used in these processes is very important for the total carbon footprint of the final product. Most of the added production capacity this century for both processes has been constructed in Asia, and in particular in China. Also, the GCC countries have become significant contributors to aluminum production. The energy mix for the electric power consumed has changed with this shift in location, but differently for the two processes.

\section{Development of Indirect Emissions in Aluminum Production}

The increase in aluminum production since 2000 has been mostly in China with almost $90 \%$ coal thermal power, and in the Middle East based on power produced from natural gas. The share of renewable energy and nuclear has been reduced from $51 \%$ in 2000 down to $28 \%$ in 2019, according to data from World Aluminum, as seen in Fig. 1 [17]. As a result of this, the contribution of indirect emissions, due to energy production, to the overall carbon footprint of the metal production, has increased by $39 \%$, from 7.2 to 10 $\mathrm{CO}_{2} \mathrm{e} / \mathrm{kg} \mathrm{Al}$, and this increase in emissions from energy production amounts to almost twice that of the emissions from the electrolysis step itself. Thus, the total global average carbon footprint from aluminum production is now $14.3 \mathrm{CO}_{2} \mathrm{e} /$ $\mathrm{kg} \mathrm{Al}$, and there of $70 \%$ are due to the production of the electric power used in the process. The development of the average carbon footprint for primary aluminum production is seen in Fig. 2. It is therefore clear that the most important opportunities for reducing the carbon footprint of aluminum are through shifting the production to low-carbon energy resources, such as renewables or nuclear power.

\section{Development of the Carbon Footprint for Metallurgical Grade Silicon Production}

Historically, the deciding factor for the site selection for silicon and ferrosilicon factories has been the access to reliable hydro-powered electrical energy, because of the reliability of supply associated with competitive energy price and low transmission cost. A number of plants were 
Fig. 1 Energy use, by source, for aluminum production in different regions of the world in 2000,2010 , and 2019 [18]
Energy use for Al production pr. year, by region and source

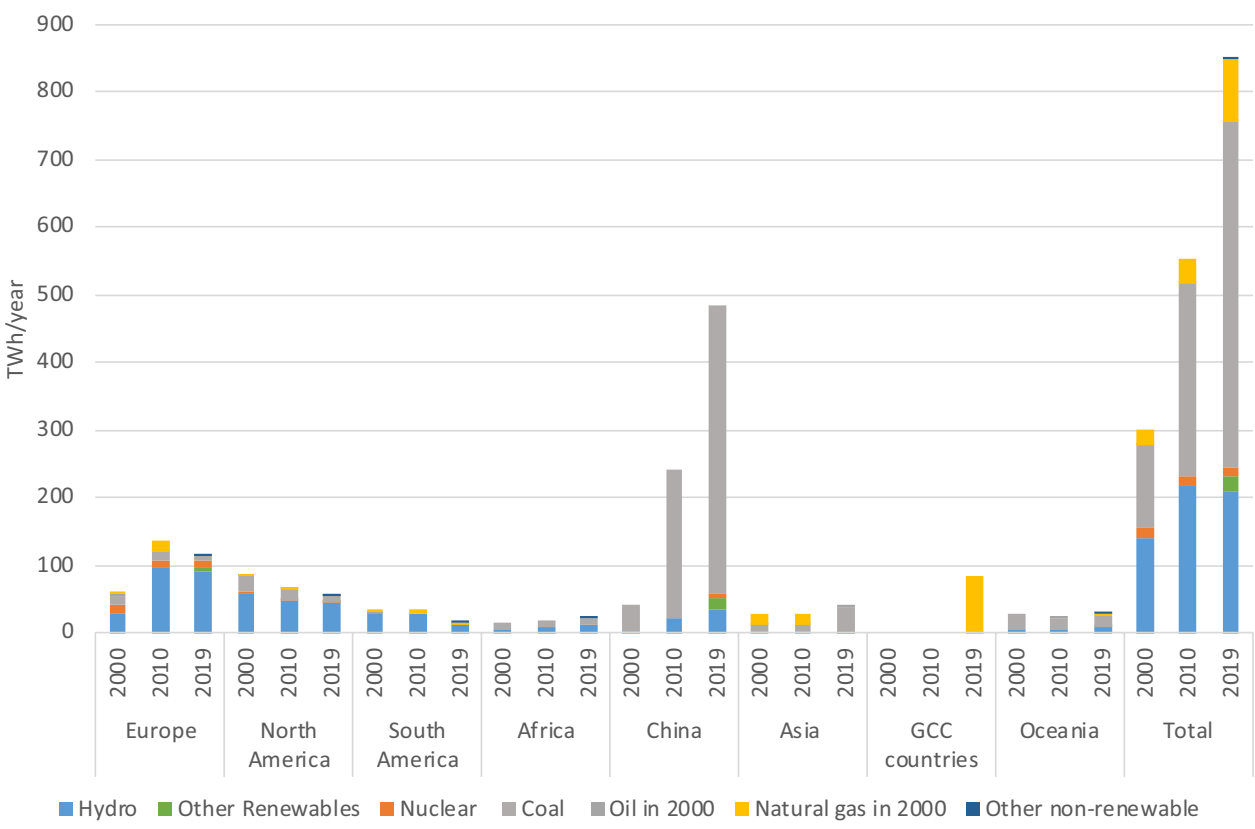

Fig. 2 The location-specific carbon footprint for aluminum electrolysis in different regions of the world and the global average in 2000, 2010, and 2019 [18-20]

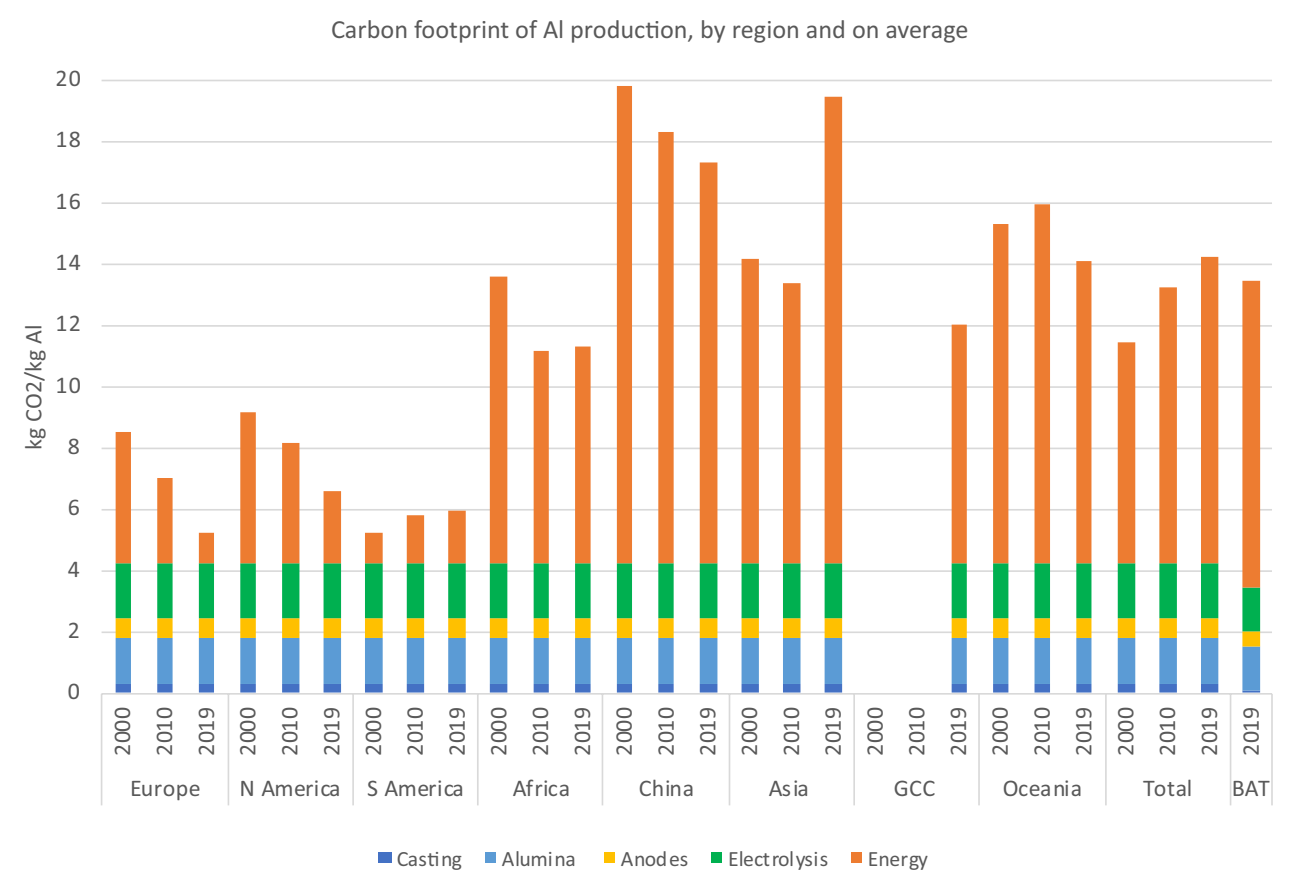

built in regions with significant contribution of nuclear power in the energy mix, which also contributes to lowering the indirect carbon footprint for silicon. The increase in silicon production in 2019 is by a factor of 2.4 since 2000 , and by a factor of 4.6 since 1995 . As for aluminum, this increase has mainly taken place in China. Access to statistics related to silicon is limited, but according to privately obtained data kindly shared by Jorn De Linde at CRU [21], the energy mix used in the process has developed differently than for aluminum. Typical silicon production plants are smaller than most modern aluminum smelters and have, to a larger extent, been built in areas with access to hydropower, as their power use can be matched up with a moderately sized hydropower plant. Also, silicon smelters have more flexibility to adapt their production to fluctuations in power supply than aluminum smelters and can be shut down without much irreparable damage to equipment, to meet conditions in the energy market. These two 
Fig. 3 Energy consumed for the production of metallurgical grade silicon by region and energy source from 1995 to 2019, data from Jorn de Linde at CRU [21]

Fig. 4 The location-specific carbon footprint for MG-silicon production, assuming constant process emissions, in different regions of the world and the global average in 2000, 2010, and 2019 [14, 19-21]
Energy, by source, used in silicon production in different regions
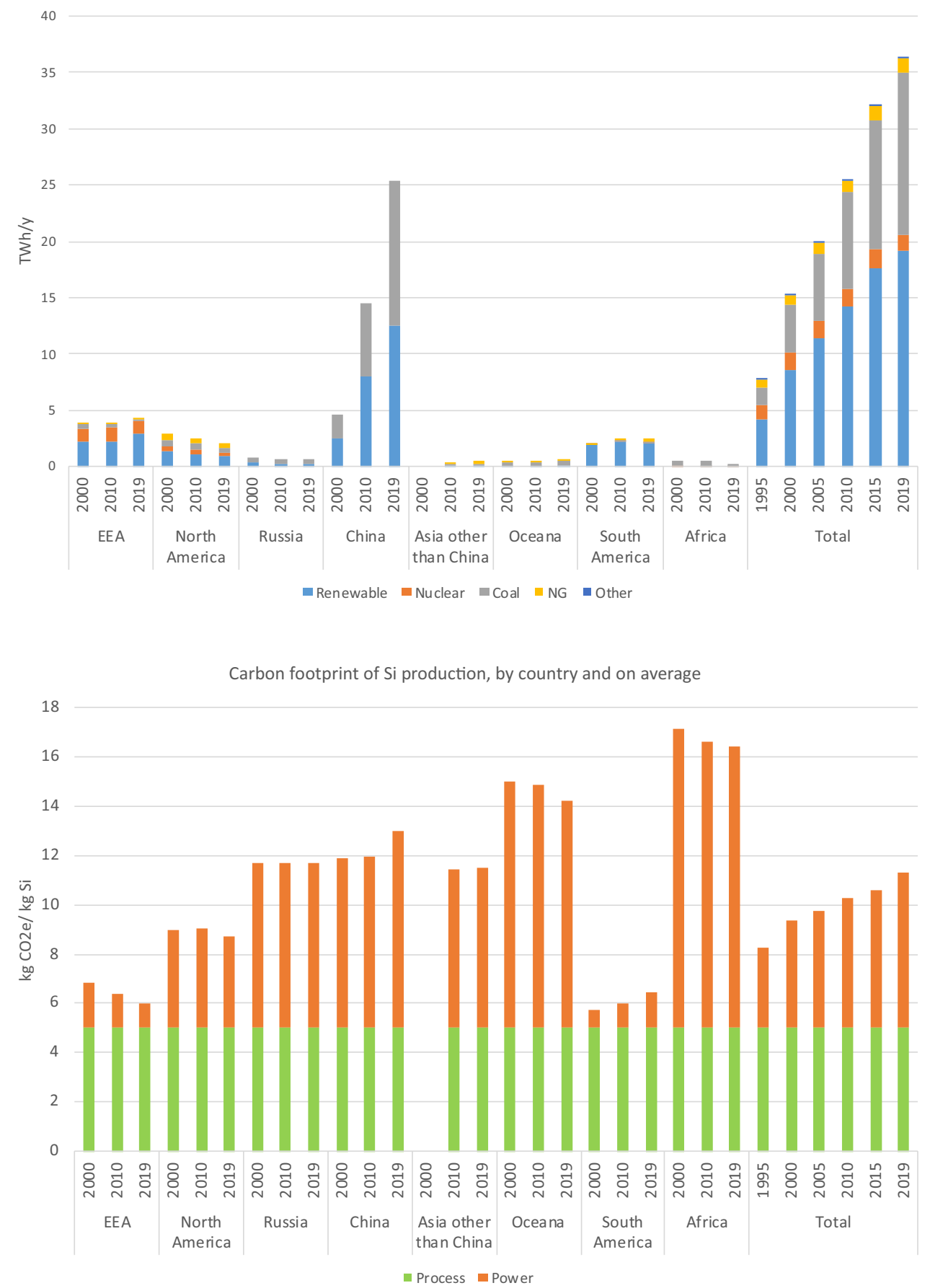

factors are likely the reason for a much higher contribution of renewables in the energy mix for silicon production than for aluminum production. The share of the low-emission sources, renewables, and nuclear energy is currently at $57 \%$, down from $67 \%$ in 2000 and $72 \%$ in 1995 . The share of coal-based energy production has increased from $19 \%$ in 1995 and $28 \%$ in 2000 to $40 \%$ in 2019 , see Fig. 3. The associate development of the carbon footprint of silicon production is shown in Fig. 4. Nevertheless, the indirect carbon footprint has increased from $4.4 \mathrm{~kg} \mathrm{CO}_{2} \mathrm{e} / \mathrm{kg} \mathrm{Si}$ in 2000 to $6.3 \mathrm{~kg} \mathrm{CO} 2 \mathrm{e} / \mathrm{kg} \mathrm{Si}$, or by $43 \%$. The increase is $90 \%$ if we compare to the year 1995. Assuming the process emission factor to be constant at $5 \mathrm{~kg} \mathrm{CO} 2 / \mathrm{kg} \mathrm{Si}$, this equals an increase in the total carbon footprint from 9.4 to $11.3 \mathrm{~kg} \mathrm{CO}_{2} \mathrm{e} / \mathrm{kg} \mathrm{Si}$ since 2000 , and currently more than half of the carbon footprint originates from the electric power production. 


\section{Reducing the Emissions from Aluminum and Silicon Production}

There are several initiatives for addressing the emissions from these production processes. One potential approach is to capture $\mathrm{CO}_{2}$ from flue gas from the existing processes and permanently sequester it, an approach called Carbon Capture and Storage (CCS). There are several options for sequestering the gas, one is the CarbFix process developed by the Icelandic power company Reykjavik Energy, who demonstrated that $\mathrm{CO}_{2}$ from the non-condensable gases in geothermal fluids, dissolved in water and pumped underground, would dissolve metallic oxides and form carbonate minerals, mostly magnesium and calcium carbonates[22]. This method is applicable for geologies where there is access to magnesium-rich mafic rock, such as volcanic basalt. In other regions of the world, pumping the $\mathrm{CO}_{2}$ into depleted hydrocarbon reservoirs can be applied, as the gas is contained by caprock formations [23].

CCS can be applied to either the silicon and aluminum processes, but in many ways the silicon process is better suited as the concentration of $\mathrm{CO}_{2}$ in the flue gas around $3-4 \%[24,25]$. This is at the low end for existing carbon capture solutions, so further up-concentration would make this stream more feasible for carbon capture. The $\mathrm{CO}_{2}$ concentration in the flue gas from aluminum production is generally not more than $1 \%$, which means that either the aluminum reduction cells and particularly the superstructure would need to be adapted to a dramatically reduced flue-gas suction rate, or that the carbon capture technology would need to be adapted to a lower $\mathrm{CO}_{2}$ concentration, which would also require increased energy use for the up-concentration process. An alternative approach to up-concentrating the flue gas, applicable to both processes, would be to cool the flue gas and recirculate it back into the cell or furnace, and patents have been issued for solutions of that type [26]. Lorentzen et al. [27], Mathisen et al. [28], and others have studied the feasibility of up-concentrating the $\mathrm{CO}_{2}$ from the flue gas for further processing.

Applying CCS to capture, the $\mathrm{CO}_{2}$ from these processes would in any case incur significant investment and higher operation cost, and increased energy use. Thus, there would not be much environmental gain unless that energy came from a low-carbon source, and international climate policies and incentives would need to be implemented to make it economically feasible for the industry.

An interesting development for aluminum is the initiatives to develop an electrolysis process with inert anodes, where oxygen is released as an anode product rather than $\mathrm{CO}_{2}[29,30]$. Then oxygen would be formed as the anode product, and $\mathrm{CO}_{2}, \mathrm{CO}$, and perfluorocarbon emissions would be eliminated from this carbon-free electrolytic process. The gain from this would be a carbon footprint reduction between 1.4 and $1.7 \mathrm{t} \mathrm{CO}_{2} \mathrm{e} / \mathrm{t} \mathrm{Al}$, depending on whether we are comparing industry best practice or typical average data with the current world operations and assuming that the changes to the process do not incur much emission. If the new inert anodes and cathodes and their raw materials can be produced with low or negligible $\mathrm{CO}_{2} \mathrm{e}$ emissions, it is fair to assume the emissions from carbon anodes and their raw materials can be removed (see Table 1). In this case, the emission reduction is 2.3 tons of $\mathrm{CO}_{2} \mathrm{e}$ emissions, or about $16 \%$ of the total emissions. With inert anodes and hydroelectric power the only main process emissions would be the 1.5 tons of $\mathrm{CO}_{2} \mathrm{e}$ coming from the production of alumina from bauxite.

It must be noted, however, that an oxygen-evolving electrolysis process for aluminum production requires more energy, as $\mathrm{O}_{2}$ is a higher energy-containing compound than $\mathrm{CO}_{2}$ [31]. If all other conditions were unchanged, the increase in energy required would be around $\sim 2.8 \mathrm{kWh} / \mathrm{kg}$ $\mathrm{Al}$, which would lead to increased total emissions if the electrical energy is from a coal thermal power plant. To compensate for the increased energy requirement for the chemical process, most inert anode cell designs are for vertical electrodes with wetted $\mathrm{TiB}_{2}$ cathodes, to enable a smaller anode-cathode distance and therefore a lower cell voltage drop as compared to the Hall-Héroult process. If or when a successful technology is developed, the benefit is greatest for the companies that have access to surplus low-carbon energy capacity, unless there is a major breakthrough in materials technologies so the cell can operate without a frozen lining. That would enable substantial heat conservation for the cells. Such breakthroughs would also prove beneficial for lowering the energy consumption of the existing cell technologies as well. Significant research and development efforts have been done and are on-going. Inert anodes for aluminum smelting are now a technology in pilot testing, with the aim of commercializing an inert anode electrolysis process. Rusal announced successful production of low-emission aluminum from $140 \mathrm{kA}$ inert anode industrial cells in their Krasnoyarsk smelter in spring 2021 [32, 33]. Elysis, which is owned by Alcoa, RTA, Apple, and the Canadian government, aims for industrial rollout of inert anode cells in 2024 [34, 35].

For the silicon production process, there are promising initiatives to develop alternative processes to produce silicon by using different reduction agents to reduce quartz. Hydrogen does not offer a thermodynamically favorable chemistry for the production of silicon metal as it does as a reduction agent for iron smelting. Hydrogen readily reduces the $\mathrm{SiO}_{2}$ to produce the intermediate $\mathrm{SiO}$ gas [36]. In the carbothermic process, the final metal producing step is obtained by a reaction between the intermediate compounds $\mathrm{SiO}$ and $\mathrm{SiC}$, but an alternative silicon forming reaction seems elusive when using only hydrogen as a reduction agent as reduction of $\mathrm{SiO}$ to $\mathrm{Si}$ by $\mathrm{H}_{2}$ is not favored by thermodynamics. Adding 
methane gas to the hydrogen flow enables $\mathrm{SiC}$ formation, which would enable Si formation at higher temperatures, but the methane content has an upper limit of a few percent to prevent methane cracking at elevated temperatures [37]. Such a process would not eliminate $\mathrm{CO}_{2}$ emissions but has a potential to significantly reduce the emissions. However, significant process development remains [38, 39], but there is a 2007 patent for Si production in a plasma furnace using methane as a reductant [40]. Another possibility is producing a $\mathrm{SiO}$ condensate, which contains $\mathrm{SiO}_{2}$ and $\mathrm{Si}$ metal as droplets. A process based on condensation is, however, not likely to be efficient enough to be viable. Electrolysis of silicon oxides in a molten salt electrolyte, or direct electrolysis from molten oxides, has also been studied [41, 42], but is at a relatively low technology readiness level at this time. According to Grjotheim et al. [43], the decomposition potential for $\mathrm{SiO}_{2}$ is $1.8 \mathrm{~V}$, while for $\mathrm{Al}_{2} \mathrm{O}_{3}$ it is $2.16 \mathrm{~V}$. As the valency for $\mathrm{Si}$ ions is +4 , while it is +3 for $\mathrm{Al}$, a third more current would be required on molar basis to reduce $\mathrm{Si}$ than $\mathrm{Al}$, while the molar mass is $28 \mathrm{~g} / \mathrm{mol}$ for Si vs. $27 \mathrm{~g} / \mathrm{mol}$ for $\mathrm{Al}$. Thus, the minimum theoretical electricity input is $7 \%$ higher to electrolyze Si than Al. As discussed before, the electric energy requirement is $12.5-16 \mathrm{kWh} / \mathrm{kg}$ to produce $\mathrm{Al}$ in the Hall-Héroult process, while the specific electrical energy consumption for MG-silicon production is in the range $10.5-13 \mathrm{kWh} / \mathrm{kg} \mathrm{Si}$. Therefore, although the energy consumption would be dependent on specific process design and associated heat loss, it is likely that an electrochemical process would require more electric energy per $\mathrm{kg} \mathrm{Si}$ than the existing process. The direct carbon footprint of silicon production can also be reduced by using renewable carbon sources in the process. This means, for example, increasing the use of charcoal and woodchips instead of coke and coal as reduction agents. The feasibility is dependent on the cost and local availability of the materials. Increased carbon taxes will make the feasibility of renewable alternatives more attractive.

\section{Discussion}

Looking at the big picture, the largest contribution to the average carbon footprint of both processes comes from the production of the electric power used in the processes. The process footprints are around $4.2 \mathrm{CO}_{2} \mathrm{e} / \mathrm{kg} \mathrm{Al}$ and $5 \mathrm{CO}_{2} \mathrm{e} /$ $\mathrm{kg} \mathrm{Si}$ and the development of solutions to address those have been discussed above. The remaining $70 \%$ of the aluminum carbon footprint and $56 \%$ of the silicon footprint are the indirect emissions, and can only be addressed by a transition to low-carbon energy sources in these processes. The development since 2000 has been in the direction of a significant increase in this part of the carbon footprint, as the center of gravity for this production has shifted away from the western world towards Asia, with more reliance on electric power from fossil fuel.

Assuming global emissions of $\sim 50$ billion tons of $\mathrm{CO}_{2} \mathrm{e} /$ year, aluminum production contributes around $1.8 \%$ of total global emissions and silicon production $0.06 \%$. These are emission sources that must be included in the global efforts to eliminate emissions and limit climate change, and the total number is the sum of many smaller contributions. It can be seen from the numbers presented in this paper that shifting production away from renewable energy in western economies with ambitious country-based emission reduction goals, in order to eliminate local process-related emission, towards more fossil fuel reliant energy mixes in other parts of the world, leads to increased total emissions from these products. That makes it less likely that the countries of the world will reach the climate goals of the Paris agreement. Although recycling is likely to contribute more to the demand for aluminum in the future, there will be a need for primary production, while most people indulge themselves with modern comforts. Recycling of silicon is a different matter as much of it is used as an ingredient in materials, such as aluminum alloys or silicones. These are not easily recyclable back to silicon. It is, therefore, imperative to keep the production processes on low-carbon energy sources, and transition the industry towards decarbonization of their processes, as addressed above. Emerging lowcarbon technologies are likely to be more costly than the mature technologies in the short term, and therefore climate policies and incentives must be in place for this development to be an economical possibility. The emerging Carbon Border Adjustment Mechanism recently announced by the European Commission [44] is one mechanism to reduce the risk of carbon leakage, and will cover aluminum production from the start. Importers will be required to do carbon reporting on imported products from 2023, and to pay for emission allowances from 2026. Although silicon production is not listed as one of the initial processes affected, due to its carbon leakage propensity it will almost certainly be included, if at a later stage.

\section{Concluding Remarks}

The carbon footprint for primary production of aluminum and silicon has increased from around 11.4 to $14.3 \mathrm{CO}_{2} \mathrm{e} / \mathrm{kg}$ $\mathrm{Al}$ and from 9.4 to $11.3 \mathrm{CO}_{2} \mathrm{e} / \mathrm{kg} \mathrm{Si}$, respectively, from 2000 to 2019. This increase in the carbon footprint is exclusively attributed to the energy mix used in the process, which has shifted towards a larger share of fossil energy with increasing production in Asia, predominantly in China. There are several on-going initiatives aimed at reducing the process related emissions, which is a primary task on the path towards carbon neutrality, either through CCS or alternative 
processes. These are likely to be more expensive in the short term than the current technology standard, which requires a regulatory framework or incentives to enable economic feasibility for the low-carbon alternatives. However, eliminating the $70 \%$ and $57 \%$, respectively, of the carbon footprint that comes from power production must be addressed very seriously if international emission targets are to be achieved.

\section{Acknowledgements Special thanks to Jorn De Linde at CRU for pro-} viding data for silicon.

Open Access This article is licensed under a Creative Commons Attribution 4.0 International License, which permits use, sharing, adaptation, distribution and reproduction in any medium or format, as long as you give appropriate credit to the original author(s) and the source, provide a link to the Creative Commons licence, and indicate if changes were made. The images or other third party material in this article are included in the article's Creative Commons licence, unless indicated otherwise in a credit line to the material. If material is not included in the article's Creative Commons licence and your intended use is not permitted by statutory regulation or exceeds the permitted use, you will need to obtain permission directly from the copyright holder. To view a copy of this licence, visit http://creativecommons.org/licenses/by/4.0/.

\section{References}

1. Masson-Delmotte V, Zhai P, Pörtner H-O, Roberts D, Skea J, Shukla PR, Pirani A, Moufouma-Okia W, Péan C, Pidcock R, Connors S, Matthews JBR, Chen Y, Zhou X, Gomis MI, Lonnoy E, Maycock T, Tignor M, Waterfield T (eds) (2018) Global warming of $1.5^{\circ} \mathrm{C}$. An IPCC special report on the impacts of global warming of $1.5^{\circ} \mathrm{C}$ above pre-industrial levels and related global greenhouse gas emission pathways, in the context of strengthening the global response to the threat of climate change, sustainable development, and efforts to eradicate poverty. Intergovernmental Panel on Climate Change, IPCC

2. Davis SJ et al (2018) Net-zero emissions energy systems. Science 360(eaas6396):793. https://doi.org/10.1126/science.aas9793

3. The Editors of Encyclopaedia Britannica (2020) Silicon. Encyclopedia Britannica

4. Saevarsdottir G, Kvande H, Welch BJ (2020) Reducing the carbon footprint: aluminium smelting with changing energy systems and the risk of carbon leakage. In: Tomsett A (ed) Light metals 2020. Springer, Cham, pp 726-734

5. World Aluminium (2021) Global aluminium cycle 2019. https:// alucycle.international-aluminium.org/public-access. Accessed 08 May 2021

6. Soo VK, Peeters J, Paraskevas D, Compston P, Doolan M, Duflou JR (2018) Sustainable aluminium recycling of end-of-life products: a joining techniques perspective. J Clean Prod 178:119-132. https://doi.org/10.1016/j.jclepro.2017.12.235

7. Saevarsdottir G, Kvande H, Welch BJ (2020) Aluminium production in the times of climate change: the global challenge to reduce the carbon footprint and prevent carbon leakage. JOM 72(1):296-308. https://doi.org/10.1007/s11837-019-03918-6

8. Haupin WE (2013) Principles of aluminum electrolysis. In: Essential readings in light metals. Wiley, Hoboken, pp 1-11. https://doi. org/10.1002/9781118647851.ch1

9. Stocker TF, Qin D, Plattner G-K, Tignor M, Allen SK, Boschung J, Nauels A, Xia Y, Bex V, Midgley PM (eds) (2013) Climate Change 2013: the physical science basis. Contribution of working group I to the fifth assessment report of the intergovernmental panel on climate change. IPCC

10. Thonstad J, Utigard TA, Vogt H (2013) On the anode effect in aluminum electrolysis. In: Essential readings in light metals. Wiley, Hoboken, pp 131-138. https://doi.org/10.1002/9781118647851. ch18.

11. Åsheim H, Aarhaug TA, Ferber A, Kjos OS, Haarberg GM (2016) Monitoring of continuous PFC formation in small to moderate size aluminium electrolysis cells. In: Grandfield J (ed) Light metals 2014. Springer, Cham, pp 535-539. https://doi.org/10.1007/ 978-3-319-48144-9_91

12. Schei A, Tuset JK, Tveit H (1998) Production of high silicon alloys. Tapir, Trondheim

13. Bernstein L, Roy J, Delhotal KC, Harnisch J, Matsuhashi R, Price L, Tanaka K, Worrell E, Yamba F, Fengqi Z (2007) Industry. In: Climate change 2007: Mitigation. Contribution of working group III to the fourth assessment report of the intergovernmental panel on climate change. Cambridge University Press, Cambridge, UK and New York, USA. https://www.ipcc.ch/site/assets/uploads/ 2018/02/ar4-wg3-chapter7-1.pdf

14. Faerden T, Tranell G, Bubetsky JS, Lindstad T, Olsen SE (2006) IPCC guidelines for national greenhouse gas inventories. [https:// www.ipcc-nggip.iges.or.jp/public/2006gl/pdf/3_Volume3/V3_4_ Ch4_Metal_Industry.pdf

15. Lindstad T, Olsen S, Tranell G, Færden T, Lubetsky J (2007) Greenhouse gas emissions from ferroalloy production. https:// www.researchgate.net/publication/238745804_GREENHOUSE_ GAS_EMISSIONS_FROM_FERROALLOY_PRODUCTION

16. Monsen B, Lindstad T, Tuset JK (1998) $\mathrm{CO}_{2}$ emissions from the production of ferrosilicon and silicon metal in Norway. In: Electric furnace conference proceedings, vol 56, New Orleans, USA

17. Saevarsdottir G, Kvande H, Magnusson T (2021) Greenhouse gas emissions from silicon production - development of carbon footprint with changing energy systems. Presented at the Infacon XVI, Trondheim, Norway

18. World Aluminium (2020) Primary aluminium smelting power consumption

19. World Aluminium (2017) A life-cycle model of Chinese grid power and its application to the life cycle impact assessment of primary aluminium. World Aluminium. https://www.world-alumi nium.org/media/filer_public/2017/06/29/lca_model_of_chinese_ grid_power_and_application_to_aluminium_industry.pdf

20. Bruckner T, Bashmakov IA, Mulugetta Y, Chum H, de la Vega Navarro A, Edmonds J, Faaij A, Fungtammasan B, Garg A, Hertwich E, Honnery D, Infield D, Kainuma M, Khennas S, Kim S, Nimir HB, Riahi K, Strachan N, Wiser R, Zhang X (2014) Climate change 2014: mitigation of climate change. In: Contribution of working group III to the fifth assessment report of the intergovernmental panel on climate change. IPCC

21. Jorn de Linde (2021) Data on silicon production

22. Pogge von Strandmann PAE et al (2019) Rapid CO2 mineralisation into calcite at the CarbFix storage site quantified using calcium isotopes. Nat Commun 10(1):1983. https://doi.org/10.1038/ s41467-019-10003-8

23. Hannis $\mathrm{S}$ et al (2017) $\mathrm{CO} 2$ storage in depleted or depleting oil and gas fields: what can we learn from existing projects? In: 13th Iinternational conference on greenhouse gas control technologies. GHGT-13 14-18 Nov 2016 Lausanne Switzerland, vol 114, pp 5680-5690. https://doi.org/10.1016/j.egypro.2017.03.1707

24. Skagestad R et al (2017) $\mathrm{CO}_{2}$ stCap-Cutting cost of $\mathrm{COS}_{2}$ capture in process industry. Energy Procedia 114:6303-6315. https://doi. org/10.1016/j.egypro.2017.03.1767

25. Mathisen A, Normann F, Bierman M, Skagestad R, Haug AT (2019) $\mathrm{CO}_{2}$ capture opportunities in the Norwegian silicon industry, presented at the TCCS-10. $\mathrm{CO}_{2}$ Capture, Transport and Storage., Trondheim, Norway, 2019. https://sintef.brage.unit.no/ 
sintef-xmlui/bitstream/handle/11250/2637936/SProceedings\% 20no\%204-s49.pdf?sequence $=1 \&$ isAllowed $=y$

26. Wedde G, Bjarno OE, Sorhuus A (2016) Recycled pot gas pot distribution. CA2814566A1, March 29, 2016

27. Lorentsen O-A, Dyrøy A, Karlsen M (2016) Handling $\mathrm{CO}_{2} E Q$ from an aluminum electrolysis cell. In: Bearne G, Dupuis $\mathrm{M}$, Tarcy G (eds) Essential readings in light metals: Volume 2 Aluminum reduction technology. Springer, Cham, pp 975-980. https://doi.org/10.1007/978-3-319-48156-2_144

28. Mathisen A, Sørensen H, Eldrup N, Skagestad R, Melaaen M, Müller GI (2013) Cost optimised $\mathrm{CO}_{2}$ capture from aluminium production. In: 7th Trondheim Conference $\mathrm{CO}_{2}$ Capture Transp. Storage 2013, vol 51, pp 184-190, Jan 2014. https://doi.org/10. 1016/j.egypro.2014.07.021

29. Yasinskiy A, Padamata SK, Polyakov PV, Shabanov AV (2020) An update on inert anodes for aluminium electrolysis. Non-Ferrous Met 48(1):12-23. https://doi.org/10.17580/nfm.2020.01.03

30. Gunnarsson G, Óskarsdóttir G, Frostason S, Magnússon JH (2019) Aluminum electrolysis with multiple vertical non-consumable electrodes in a low temperature electrolyte. In: Chesonis C (ed) Light metals 2019. Springer, Cham, pp 803-810

31. Kvande H, Haupin W (2001) Inert anodes for Al smelters: Energy balances and environmental impact. JOM 53(5):29-33. https://doi. org/10.1007/s11837-001-0205-6

32. Staff (2021) Rusal sets new low for carbon dioxide output in primary aluminium production. Aluminium Insider, April 14, 2021. https://aluminiuminsider.com/rusal-sets-new-low-for-carbon-dioxi de-output-in-primary-aluminium-production/. Accessed 05 Aug 2021

33. Hume N (2019) Rusal targets 2021 to roll out carbon-free aluminium. Financial Times, April 01, 2019. https://www.ft.com/ content/e4a0f8f6-5252-11e9-b401-8d9ef1626294

34. Editorial (2018) Aluminium producers promise a cleaner smelting pot. Nature 557(280):18-18. https://doi.org/10.1038/ d41586-018-05158-1

35. Christ V (2019) The aluminium industry revolution at our doorstep, presented at the TMS 2019, San Antonio, Texas, March 11,
2019 annual meeting \& exhibition. https://www.tms.org/tms2019/ downloads/lmkeynote/FINAL_Christ.pdf

36. Han G, Sohn HY (2005) Kinetics of the hydrogen reduction of silica incorporating the effect of gas-volume change upon reaction. J Am Ceram Soc 88(4):882-888. https://doi.org/10.1111/j. 1551-2916.2005.00144.x

37. Li X, Zhang G, Tang K, Ostrovski O, Tronstad R (2015) Carbothermal reduction of quartz in methane-hydrogen-argon gas mixture. Metall Mater Trans B 46:2384-2393. https://doi.org/10. 1007/s11663-015-0407-x

38. Aarnæs TS, Ringdalen E, Tangstad M (2020) Silicon carbide formation from methane and silicon monoxide. Sci Rep 10(1):21831. https://doi.org/10.1038/s41598-020-79006-6

39. Monsen B, Kolveinsen L, Prytz S, Tang K (2013) Possible use of natural gas for silicon or ferrosilicon production. In: Proceedings of Infacon 13, Almaty, Kazakhstan, vol 1. https://www.pyro.co. za/InfaconXIII/0467-Monsen.pdf

40. Sörvik AI (2007) Method for the manufacture of pure silicon metal and amorphous silica by reduction of quartz. WO 2007/102745 Al

41. Ge J, Zou X, Almassi S, Ji L, Chaplin BP, Bard AJ (2019) Electrochemical production of Si without generation of $\mathrm{CO}(2)$ based on the use of a dimensionally stable anode in molten $\mathrm{CaCl}(2)$. Angew Chem Int Ed Engl 58(45):16223-16228. https://doi.org/ 10.1002/anie.201905991

42. Lee SC, Hur JM, Seo CS (2008) Silicon powder production by electrochemical reduction of $\mathrm{SiO}_{2}$ in molten $\mathrm{LiCl}-\mathrm{Li}_{2} \mathrm{O}$. J Ind Eng Chem 14(5):651-654. https://doi.org/10.1016/j.jiec.2008.04.010

43. Grjotheim K, Matiasovsky K (1983) Impurities in the aluminium electrolyte. Aluminium 59(9):687-693

44. European Commission (2021) Carbon border adjustment mechanism: questions and answers. European Commission. https://ec. europa.eu/commission/presscorner/detail/en/qanda_21_3661. Accessed 05 Aug 2021

Publisher's Note Springer Nature remains neutral with regard to jurisdictional claims in published maps and institutional affiliations.

\section{Authors and Affiliations}

\section{Gudrun Saevarsdottir $^{1}$ (i) $\cdot$ Thordur Magnusson $^{2} \cdot$ Halvor Kvande $^{3}$}

Gudrun Saevarsdottir

gudrunsa@ru.is

1 Reykjavik University, Reykjavik, Iceland

2 Normi Ehf., Kopavogur, Iceland
3 Norwegian University of Science and Technology, Trondheim, Norway 